\title{
Transatlantica
}

Revue d'études américaines. American Studies Journal

1 | 2017

Morphing Bodies: Strategies of Embodiment in

Contemporary US Cultural Practices

\section{Sandra Lee Kleppe, The Poetry of Raymond Carver. Against the Current}

\section{Claire Fabre-Clark}

\section{(2) OpenEdition}

Journals

Electronic version

URL: https://journals.openedition.org/transatlantica/9191

DOI: 10.4000/transatlantica.9191

ISSN: 1765-2766

Publisher

Association française d'Etudes Américaines (AFEA)

Electronic reference

Claire Fabre-Clark, "Sandra Lee Kleppe, The Poetry of Raymond Carver. Against the Current",

Transatlantica [Online], 1 | 2017, Online since 16 October 2018, connection on 21 May 2021. URL:

http://journals.openedition.org/transatlantica/9191 ; DOI: https://doi.org/10.4000/transatlantica.9191

This text was automatically generated on 21 May 2021.

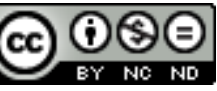

Transatlantica - Revue d'études américaines est mise à disposition selon les termes de la licence Creative Commons Attribution - Pas d'Utilisation Commerciale - Pas de Modification 4.0 International. 


\title{
Sandra Lee Kleppe, The Poetry of Raymond Carver. Against the Current
}

\author{
Claire Fabre-Clark
}

\section{REFERENCES}

Sandra Lee Kleppe, The Poetry of Raymond Carver. Against the Current , Ashgate Publishing Limited, Farnham, England /Burlington VT USA, 2014, 200 pages, 108,29 €; ISBN:

9781472411679

1 While he was publishing short stories, Carver never ceased writing - and publishing poems that came out in six volumes during his lifetime and were later collected into one volume by Tess Gallagher and William Stull (All of Us: The Collected Poems, 1996). This book offers a very original analysis of Carver's poetry in the light of recent literary theories that take into account the latest developments of hard sciences (in Neuroscience, in particular). Carver's poetry has been given far less critical attention than his short fiction, and when it did attract consideration, it was rarely treated as a whole but rather elicited readings of specific poems. With Sandra Lee Kleppe's groundbreaking study, this gap is now filled, as her close readings of individual poems are always related to wider and more theoretical viewpoints on the whole oeuvre. The essay is divided into three parts which move from the complex relationship Carver's texts entertain with intertextuality (Part I) to their particular form of self-referentiality (Part II) and finally, to a closer look at the importance of the medical paradigm in the poems (Part III).

2 The introduction offers a very illuminating vision of all the concepts that will be called upon in the subsequent analyses. The overarching concept that Sandra Kleppe summons is that of "autopoetics," which "refers to the phenomenon that complex systems, whether social, genetic, literary, or other, self-reflect and self-produce" (2), based on Ira Livingston's recent book Between Science and Literature: An Introduction to Autopoetics (University of Illinois Press, 2006). Thus the poem entitled "The Current" 
serves both as example and paradigm of Carver's complex self-reflexive poetics: for Kleppe, the blind fish swimming "against the current" and invading the poet's dreams at night is an image of Carver's obstinacy in writing against the literary Doxa of his time. This trope is naturally linked to those of sight and voyeurism which have already been studied at length in his short stories, but are here re-examined in the light of "autopoetics."

3 At this point, one should underline the extremely rigorous and didactic construction of the book: each part is preceded by a theoretical preface, humbly entitled respectively "A Brief History of Intertextuality" (Part I: The Autopoetics of Outside and Inside"), "A Brief History of Self-referential Literature" (Part II: Self-Referential Poems) and finally, "A Brief History of Literature and Medicine" (Part III: De/Composition). These theoretical reviews, aptly placed at the threshold of each section, legitimize the author's use of the most contemporary (and often interdisciplinary) critical tools.

In Part I, Kleppe makes a distinction between intra-textuality (Carver quoting his own work) and inter-textuality (Carver making references to other texts). Both procedures are present in the poems, which often stage a narrator, or a narrative stance to which is added the twist of self-referentiality. What Kleppe calls the "meme" of voyeurism (thus using a biological term), is revisited through her fine study of "Woman Bathing," "The Man Outside" and "Locking Yourself Out, Then Trying to Get Back In." Not only does the motif of the voyeur provide the dramatic scenes of the poems, but it also posits a writer as voyeur, who connects the inside and the outside, and whose task is to "(communicate) secrets to the reader without violating the intimacy of the people portrayed" (37). In Kleppe's view, Carver's special brand of voyeurism, based on "involved spectators," is at the root of his autopoetics: "The insertion of involved spectators in Carver's works can be seen as an autopoetic experiment which moves towards breaching the gap between a world in which characters experience a profound disconnectedness or objectification and one in which communion is possible through gestures of eye contact, touch and invitations to empathy" (38). In the last chapter of Part I, Kleppe moves to the exploration of Carver's intratextual references through the study of the crossovers between poems and stories, namely between "Distress Sale" and its twin story "Why Don't You Dance?"; between "Late Night with Fog and Horses" and "Blackbird Pie" and finally between "Mother" and "Boxes." The close readings of these texts show that Carver's aesthetics cannot be reduced to minimalism; on the contrary, it relies on a very elaborate system of connections, echoes and intertextual references.

5 In the second part ("Self-Referential Poems"), Kleppe turns more specifically to Carver's love and nature poems. Several poems are studied in the first chapter of the section, entitled "All Poems Are Love Poems": "This Word Love" (from which the chapter derives its title), "For Semra, With Martial Vigor" and "The Blue Stones," to name the most important ones. In these poems, carnal love and writing are closely associated in texts that openly stage their own creative process and weave several intertextual references from Khayyham's Rubayaiyat to Flaubert's Madame Bovary. Nature poems from Near Klamath (1968) and At Night the Salmon Move (1976), which all converge in the themes of water, fish and fishing, are also considered from the point of view of self-reflexivity. Here again, surface meanings are wrought with references to the creative processes. The metaphorical value of the water motif is confirmed in the posthumous collection A New Path to the Waterfall (1989). 
6 The last section of the book ("De/Composition") focuses on the links between Carver's texts and medicine. After examining the connections which have always existed between medicine and literature (the filiation with William Carlos Williams is reminded here), she focuses on Carver's own obsession with medical facts, both before and after he was diagnosed with cancer. Looking closely at such poems as "Ask Him" and "Your Dog Dies" enables Kleppe to suggest that Carver revives the tradition of the Elegy, (including the "mock elegy") adding to the traditional features of "lament, praise and consolation" those of self-consciousness and critical distance. Finally, she looks at poems dealing explicitly with illness and suffering, some of which Carver wrote before being ill like "The Mailman as Cancer Patient" and others afterwards, like "Poem For Dr. Pratt." The latter thus belongs to the genre dubbed "metapathography" by Peter W. Graham in which the ill author is both "agent and author of his own experience" (147). Although in these poems one finds echoes of modernist poets like William Carlos Williams and T.S. Eliot, Kleppe insists on Carver's new and original voice and on his endeavor to move "away from a modernist aesthetic of ambiguity and postmodern theme of dissociation to a more humanistic attempt at a reconciliation of the fragmented and objectified bits of body and personhood" (155).

7 Intertwining classical theory and some of the most recent propositions in literary criticism, this synthetic study brings to light essential mechanisms in Carver's poetry and has certainly opened the way to further explorations.

INDEX

Subjects: Recensions

\section{AUTHORS}

\section{CLAIRE FABRE-CLARK}

Université Paris Est - Créteil 